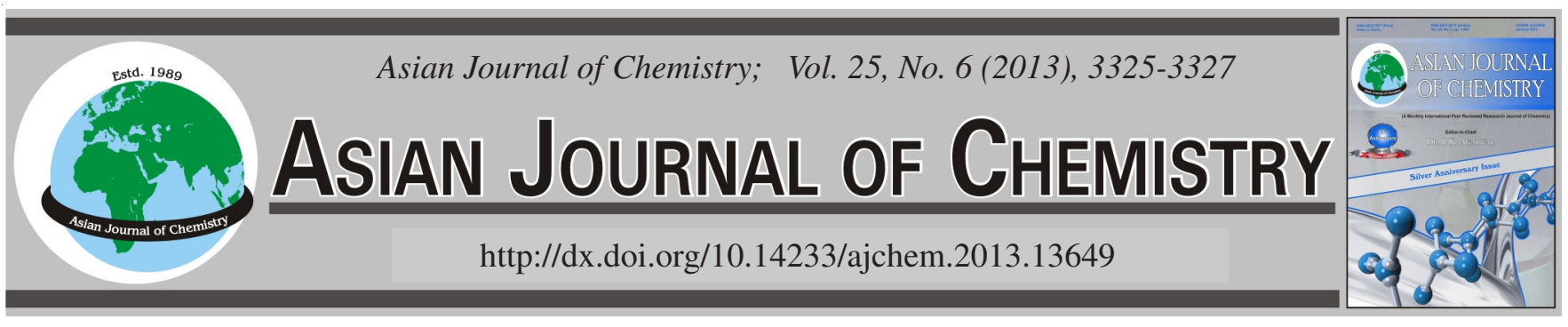

\title{
Synthesis and Metal Ion Probe Properties of Four 1,8-Naphthalimides
}

\author{
Qian LiU ${ }^{1}$, Yilin FAnG ${ }^{2}, \mathrm{XIANGHUI}^{3}{ }^{3}$, Rui $\mathrm{CHEN}^{4, *}$ and Ye Zhang ${ }^{3, *}$
}

${ }^{1}$ Department of Mathematics and Physics, Wuzhou College, Guangxi 543002, P.R. China

${ }^{2}$ School of Chemistry and Chemical Engineering, Guangxi Normal University, Guangxi 541004, P.R. China

${ }^{3}$ Department of Chemistry, Guilin Normal College, Guangxi 541001, P.R. China

${ }^{4}$ College of Chinese Medical Science, Guangxi University of Chinese Medicine, Nanning 530222, P. R. China

*Corresponding author: Fax: +86 77 32806321; Tel: +86 77 32823285; E-mail: zhangye_81@yahoo.com.cn

Four 1,8-naphthalimide derivatives (3a-3d) were designed and synthesized from 1,8-naphthalic anhydride and their structures were characterized by ${ }^{1} \mathrm{H}$ NMR and MS. Their recognition ability to metal ions was then investigated. The results showed the quenching constants $\left(\mathrm{K}_{\mathrm{CV}}\right)$ and binding constants $\left(\mathrm{K}_{\mathrm{a}}\right)$ values were found in the range of $10^{2}-10^{4} \mathrm{M}^{-1}$, indicating important metal ions recognition abilities of compounds $\mathbf{3 a - 3 d}$. All the compounds showed recognition of ferric ion, while compounds $\mathbf{3 a - 3 d}$ showed the best recognition ability of silver, cadmium, ferric and ferrous ions, respectively.

Key Words: 1,8-Naphthalimides, Synthesis, Recognition, Metal ions.

\section{INTRODUCTION}

It is well known that metal ions play an important role in many foundamental physiological processes of organisms. As rich element $(\mathrm{K}, \mathrm{Ca}, \mathrm{Mg}$, etc. $)$ and trace elements $(\mathrm{Co}, \mathrm{Ni}$, etc $)$ are essential elements for human body, the balance of their absorption and need do much to human's health. Whereas some metal ions, such as lead and cadmium are heavy metal pollutants, can deposit in organism body through various ways and do harm to organism body ${ }^{1,2}$. Therefore, it is important to effectively detect metal ions and that lead to the presence of metallic ion probes. Among many kinds of metallic ion probes, fluorescence probe which can selectively detect, signal and recognize the presence of metallic ions by the change of their fluorescence emission has attracted considerable interest ${ }^{3-9}$. Thus design and synthesis of novel fluorescent molecular probe had become hot subject in bioorganic chemistry.

1,8-Naphthalimides showed good fluorescence and excellent photostability, were usually introduced as fluorophore group $^{10,11}$ and widely used for high sensitivity fluorescent tracer and optical chemical sensors. So in this paper, four 1,8naphthalimide were designed and synthesized and their metal ion recognition properties were also studied (Scheme-I).

\section{EXPERIMENTAL}

All reagents for synthesis were commercially available and employed as received or purified by standard methods prior to use. The ${ }^{1} \mathrm{H}$ NMR studies were carried out by the

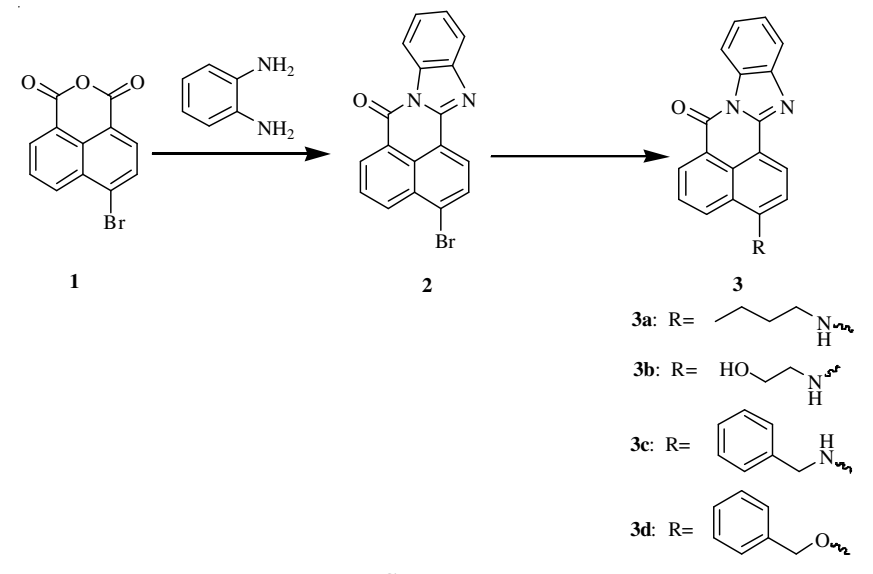

Scheme-I

BRUKER AVANCE 500 instrument and the mass spectral studies were done using BRUKER ESQUIRE HCT instrument. Melting points were recorded using an electrothermal-WRS$1 \mathrm{~A}$ melting point apparatus and were uncorrected. UV-VIS absorption spectrums were measured in the TU-1901 spectrophotometer. Fluorescence spectra were recorded in the RF5301 fluorospectrophotometer.

\section{General procedure}

Synthesis of compound 2: The mixture of 4-bromo-1,8naphthalic anhydride $(10 \mathrm{mmol})(\mathbf{1})$ and $o$-phenylenediamine $(11 \mathrm{mmol})$ was refluxed in glacial acetic acid $(50 \mathrm{~mL})$ for $6 \mathrm{~h}$. 
Crude product was washed by anhydrous ethanol and was filtered to give compound $\mathbf{2}$ as yellow crystals.

2: Yields $87 \%,{ }^{1} \mathrm{H}$ NMR $\left(\mathrm{CDCl}_{3}, 500 \mathrm{MHz}\right) \delta: 8.92$ (dd, $J=7.5 \mathrm{~Hz}, 1 \mathrm{H}, \mathrm{ArH}), 8.71(\mathrm{t}, J=7.5 \mathrm{~Hz}, 1 \mathrm{H}, \mathrm{ArH}), 8.57$ (dd, $J=7.5 \mathrm{~Hz}, 2 \mathrm{H}, \mathrm{ArH}), 8.14$ (dd, $J=7.5 \mathrm{~Hz}, 1 \mathrm{H}, \mathrm{ArH}), 7.92$ (m, $2 \mathrm{H}, \mathrm{ArH}), 7.52$ (dd, $J=2.5 \mathrm{~Hz}, 2 \mathrm{H}, \mathrm{ArH})$.

Synthesis of compound 3: The mixture of compound 2 (10 mmol) and different amine or benzyl alcohol $(12 \mathrm{mmol})$ was refluxed in ethylene glycol monomethyl ether $(50 \mathrm{~mL})$ with copper sulphate as catalyzer for $6 \mathrm{~h}$, then the crude produce was purified by column chromatography to give $\mathbf{3}$ as yellow-purple crystals.

3a: Yields $70 \%$, m.p. 200.2-202.8 ${ }^{\circ} \mathrm{C},{ }^{1} \mathrm{H}$ NMR $\left(\mathrm{CDCl}_{3}\right.$, $500 \mathrm{MHz}) \delta: 8.87(\mathrm{~d}, J=5 \mathrm{~Hz}, 1 \mathrm{H}, \mathrm{ArH}), 8 . .64(\mathrm{~d}, J=5 \mathrm{~Hz}$, $1 \mathrm{H}, \mathrm{ArH}), 8.00$ (d, $J=5 \mathrm{~Hz}, 1 \mathrm{H}, \mathrm{ArH}), 7.91(\mathrm{dd}, J=5 \mathrm{~Hz}, 1 \mathrm{H}$, ArH), 7.69 (dd, $J=7.5 \mathrm{~Hz}, 1 \mathrm{H}, \mathrm{ArH}), 7.48$ (d, $J=5 \mathrm{~Hz}, 1 \mathrm{H}$, ArH), 6.77(dd, $J=2.5 \mathrm{~Hz}, 1 \mathrm{H}, \mathrm{ArH}), 3.42(\mathrm{~d}, J=7.5 \mathrm{~Hz}, 2 \mathrm{H}$, $\mathrm{CH}_{2}$ ), 1.82 (q, $\left.J=7.5 \mathrm{~Hz}, 2 \mathrm{H}, \mathrm{CH}_{2}\right), 1.36-1.39$ (m, $J=12.5$ $\mathrm{Hz}, 1 \mathrm{H}, \mathrm{NH}), 1.29-1.32\left(\mathrm{~m}, J=10 \mathrm{~Hz}, 4 \mathrm{H}, \mathrm{CH}_{2}\right), 1.07(\mathrm{~d}, J=$ $\left.7.5 \mathrm{~Hz}, 3 \mathrm{H}, \mathrm{CH}_{3}\right), \mathrm{MS} \mathrm{m} / \mathrm{z}(\%): 342(\mathrm{M}+\mathrm{H})$.

3b: Yields $80 \%$, m.p. $230.6-232.2{ }^{\circ} \mathrm{C},{ }^{1} \mathrm{H}$ NMR $\left(\mathrm{CDCl}_{3}\right.$, $500 \mathrm{MHz}) \delta: 8.28(\mathrm{~d}, J=7.5 \mathrm{~Hz}, 1 \mathrm{H}, \mathrm{ArH}), 8.16(\mathrm{~d}, J=7.5$ $\mathrm{Hz}, 1 \mathrm{H}, \mathrm{ArH}), 8.01$ (d, $J=7.5 \mathrm{~Hz}, 1 \mathrm{H}, \mathrm{ArH}), 7.64$ (dd, $J=7.5$ $\mathrm{Hz}, 1 \mathrm{H}, \mathrm{ArH}), 7.59$ (d, $J=7.5 \mathrm{~Hz}, 1 \mathrm{H}, \mathrm{ArH}), 7.22$ (dd, $J=7.5$ $\mathrm{Hz}, 2 \mathrm{H}, \mathrm{ArH}), 7.18$ (d, J=7.5 Hz, 1H, ArH), 4.0 (t, 1H, NH), $3.65(\mathrm{~s}, 1 \mathrm{H}, \mathrm{OH}), 3.58\left(\mathrm{q}, J=7.1 \mathrm{~Hz}, 2 \mathrm{H}, \mathrm{CH}_{2}\right) 3.48(\mathrm{q}, J=$ $\left.7.1 \mathrm{~Hz}, 2 \mathrm{H}, \mathrm{CH}_{2}\right)$. MS m/z (\%): $330(\mathrm{M}+\mathrm{H})$.

3c: Yields $72 \%$, m.p. $260.1-261.8{ }^{\circ} \mathrm{C},{ }^{1} \mathrm{H}$ NMR $\left(\mathrm{CDCl}_{3}\right.$, $500 \mathrm{MHz}) \delta: 8.28(\mathrm{~d}, J=7.5 \mathrm{~Hz}, 1 \mathrm{H}, \mathrm{ArH}), 8.16(\mathrm{~d}, J=7.5$ $\mathrm{Hz}, 1 \mathrm{H}, \mathrm{ArH}), 8.01$ (d, $J=7.5 \mathrm{~Hz}, 1 \mathrm{H}, \mathrm{ArH}), 7.64$ (dd, $J=7.5$ $\mathrm{Hz}, 1 \mathrm{H}, \mathrm{ArH}), 7.59$ (d, $J=7.5 \mathrm{~Hz}, 1 \mathrm{H}, \mathrm{ArH}), 7.28$ (d, $J=7.55$ $\mathrm{Hz}, 1 \mathrm{H}, \mathrm{ArH}), 7.22$ (dd, $J=7.5 \mathrm{~Hz}, 2 \mathrm{H}, \mathrm{ArH}), 7.20$ (dd, $J=$ $7.5 \mathrm{~Hz}, 2 \mathrm{H}, \mathrm{ArH}), 7.18$ (d, $J=7.5 \mathrm{~Hz}, 1 \mathrm{H}, \mathrm{ArH}), 6.81$ (dd, $J=$ $7.5 \mathrm{~Hz}, 1 \mathrm{H}, \mathrm{ArH}), 4.0$ (s, 1H, NH). $\mathrm{MS}_{\mathrm{m} / \mathrm{z}}(\%): 374(\mathrm{M}-\mathrm{H})$.

3d: Yields $60 \%$, m.p. $270.3-272.1{ }^{\circ} \mathrm{C},{ }^{1} \mathrm{H}$ NMR $\left(\mathrm{CDCl}_{3}\right.$, $500 \mathrm{MHz}) \delta: 8.28$ (d, $J=7.5 \mathrm{~Hz}, 1 \mathrm{H}, \mathrm{ArH}), 8.23$ (d, $J=7.5$ $\mathrm{Hz}, 1 \mathrm{H}, \mathrm{ArH}), 8.16$ (d, $J=7.5 \mathrm{~Hz}, 1 \mathrm{H}, \mathrm{ArH}), 8.01$ (d, $J=7.5$ $\mathrm{Hz}, 1 \mathrm{H}, \mathrm{ArH}), 7.64$ (d, $J=7.5 \mathrm{~Hz}, 1 \mathrm{H}, \mathrm{ArH}), 7.58$ (d, $J=7.5$ $\mathrm{Hz}, 1 \mathrm{H}, \mathrm{ArH}), 7.49$ (d, $J=7.5 \mathrm{~Hz}, 1 \mathrm{H}, \mathrm{ArH}), 7.42$ (d, $J=7.5$ $\mathrm{Hz}, 1 \mathrm{H}, \mathrm{ArH}), 7.21$ (d, $J=7.5 \mathrm{~Hz}, 1 \mathrm{H}, \mathrm{ArH}), 7.20$ (dd, $J=7.5$ $\mathrm{Hz}, 2 \mathrm{H}, \mathrm{ArH}), 7.18$ (dd, $J=7.5 \mathrm{~Hz}, 1 \mathrm{H}, \mathrm{ArH}), 6.51$ (d, $J=7.5$ $\mathrm{Hz}, 1 \mathrm{H}, \mathrm{ArH}), 6.48$ (d, J = 7.5 Hz, 1H, ArH), 3.52 (s, 2H, $\left.\mathrm{CH}_{2}\right), 3.19$ (s, 2H, $\left.\mathrm{CH}_{2}\right)$. MS m/z (\%): $377(\mathrm{M}+\mathrm{H})$.

Recognition ability to metal ions detected by fluorescence spectroscopy: The metallic ion recognition properties of the compounds $\mathbf{3}$ were investigated by fluorescence quenching spectroscopy. At room temperature, compounds $\mathbf{3}$ and metal ions nitrate $\left(\mathrm{NaNO}_{3}, \mathrm{KNO}_{3}, \mathrm{Mg}\left(\mathrm{NO}_{3}\right)_{2}, \mathrm{Fe}\left(\mathrm{NO}_{3}\right)_{2}, \mathrm{Fe}\left(\mathrm{NO}_{3}\right)_{3}\right.$, $\mathrm{Cd}\left(\mathrm{NO}_{3}\right)_{2}, \mathrm{~Pb}\left(\mathrm{NO}_{3}\right)_{2}, \mathrm{Co}\left(\mathrm{NO}_{3}\right)_{2}, \mathrm{Cu}\left(\mathrm{NO}_{3}\right)_{2}, \mathrm{AgNO}_{3}, \mathrm{Ni}\left(\mathrm{NO}_{3}\right)_{2}$ and $\left.\mathrm{Zn}\left(\mathrm{NO}_{3}\right)_{2}\right)$ were dissolved in DMF-water (7:3, v:v) to proper concentration, respectively. The fluorescence spectroscopy was scanned in the RF-5301 fluorospectrophoto meter after mixed solution reached a steady state.

Recognition ability to metal ions confirmed by UVvisible spectrum: At room temperature, compounds 3 and metal ions nitrate $\left[\mathrm{KNO}_{3}\right.$ and $\left.\mathrm{Fe}\left(\mathrm{NO}_{3}\right)_{3}\right]$ were dissolved in DMF-water (7:3, v:v) to proper concentration, respectively. The UV-visible spectrum was scanned in the TU-1901 spectrophotometer after mixed solution reached a steady state.

\section{RESULTS AND DISCUSSION}

Illustrated by the case of compound $\mathbf{3 b}$, the fluorescence spectra of the compound $\mathbf{3 b}$ in the presence of various concentrations of metal ion was shown in Fig. 1. As shown in Fig. 1(A), it showed no recognition to $\mathrm{Na}^{+}, \mathrm{K}^{+}, \mathrm{Mg}^{2+}, \mathrm{Ni}^{2+}$, $\mathrm{Cu}^{2+}$. And $\mathrm{Pb}^{2+}, \mathrm{Zn}^{2+}, \mathrm{Fe}^{2+}, \mathrm{Ag}^{+}$had a little effect on the fluorescence of compound $\mathbf{3 b}$. The adding of $\mathrm{Co}^{2+}$ caused fluorescence of compound $\mathbf{3 b}$ reduced without regularity, while adding of $\mathrm{Fe}^{3+}, \mathrm{Cd}^{2+}$ caused fluorescence linear weak, as shown in Fig. 1(B).
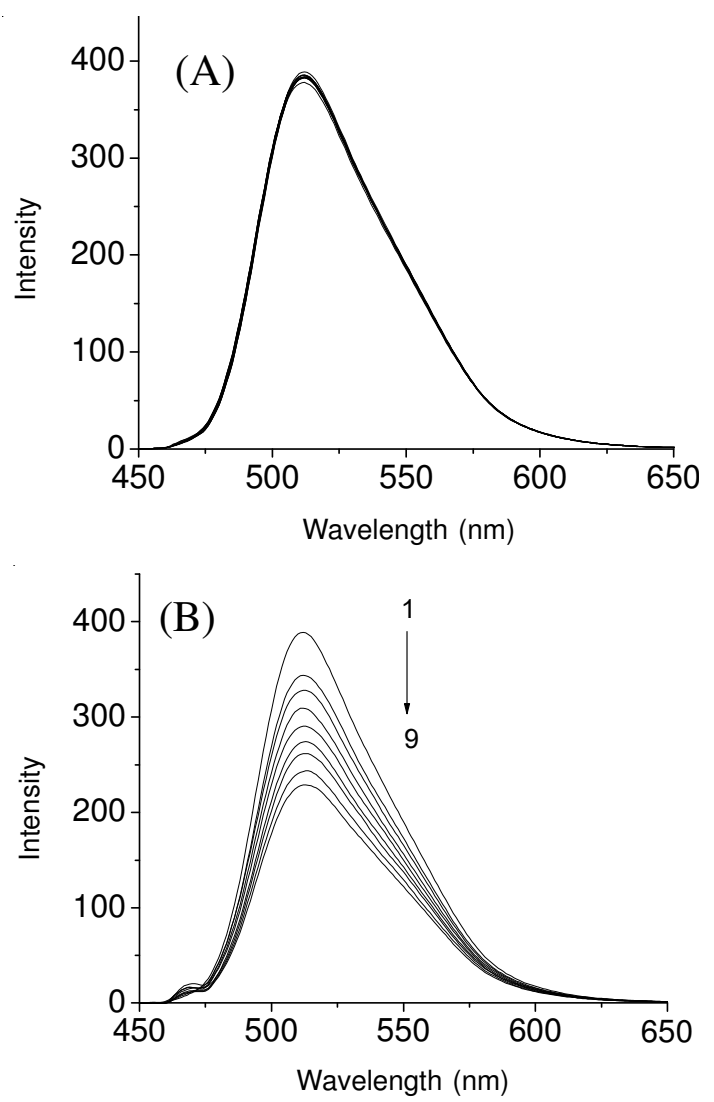

Fig. 1. Fluorescence spectra of the compound $\mathbf{3 b}$ in the presence of various concentrations of sodium (A) and ferric (B) ions. The concentrations of $\mathrm{Fe}^{3+}: 1 \rightarrow 9$ were $0,1.0,2.0,3.0,4.0,5.0,6.0,7.0,8.0 \times 10^{-4} \mathrm{~mol}$ $\mathrm{L}^{-1}$, respectively

Fluorescence quenching of compound $\mathbf{3}$ by metal ions was confirmed by the Stern-Volmer eqn. ${ }^{12,13} 1$ and modified Stern-Volmer eqn. ${ }^{12,13} 2$ as shown in Fig. 2 and the values of Stern-Volmer quenching constant $\left(\mathrm{K}_{\mathrm{CV}}\right)$ and binding constants $\left(\mathrm{K}_{\mathrm{a}}\right)$ were showed in the Tables 1 and 2, respectively.

$$
\begin{gathered}
\frac{\mathrm{F}_{0}}{\mathrm{~F}}=1+\mathrm{K}_{\mathrm{q}} \tau_{0} \mathrm{c}(\mathrm{Q})=1+\mathrm{K}_{\mathrm{cv}} \mathrm{c}(\mathrm{Q}) \\
\frac{\mathrm{F}_{0}}{\mathrm{~F}_{0}-\mathrm{F}}=\frac{\mathrm{F}_{0}}{\Delta \mathrm{F}}=\frac{1}{\mathrm{f}_{\mathrm{a}} \mathrm{K}_{\mathrm{a}} \mathrm{c}(\mathrm{Q})}+\frac{1}{\mathrm{f}_{\mathrm{a}}}
\end{gathered}
$$

As shown in Tables 1 and 2, all the compounds showed recognition to ferric ion and the quenching constant $\left(\mathrm{K}_{\mathrm{CV}}\right)$ and binding constants $\left(\mathrm{K}_{\mathrm{a}}\right)$ values were in the range of $10^{2}-10^{3} \mathrm{M}^{-1}$. The order was: $\mathbf{3 c}>\mathbf{3 b}>\mathbf{3} \mathbf{a}>\mathbf{3 d}$. It was possibly due to that ferric ion had strong oxidative which made the fluorescence quenching phenomenon stronger. In addition, the electron 

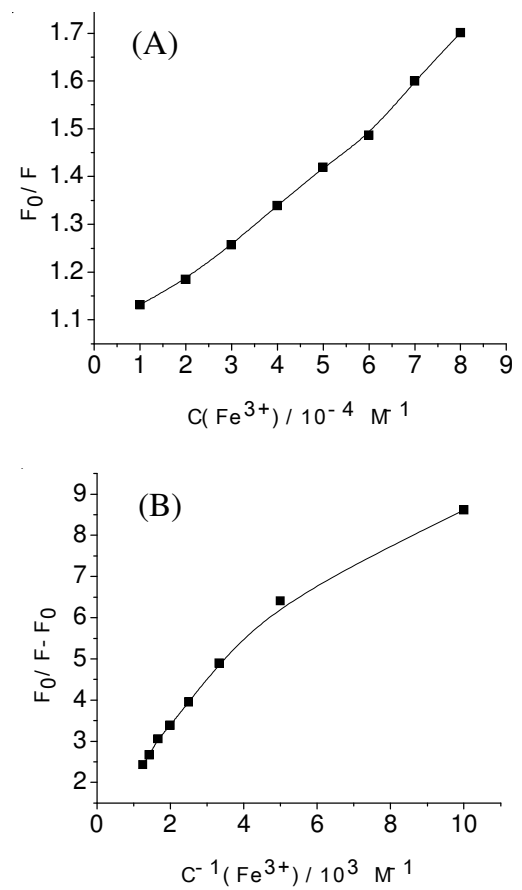

Fig. 2. Stern-volmer plots (A) and Modifed Stern-volmer plots (B) for the quenching of $\mathbf{3 b}$ by ferric ion

\begin{tabular}{|c|c|c|c|c|}
\hline \multicolumn{5}{|c|}{$\begin{array}{c}\text { TABLE-1 } \\
\text { THE QUENCHING CONSTANT }\end{array}$} \\
\hline Compound & $\begin{array}{c}\mathrm{K}_{\mathrm{CV} / \mathrm{Fe}}^{3+} \\
\left(\mathrm{L} \mathrm{mol}^{-1}\right)\end{array}$ & $\begin{array}{l}\mathrm{K}_{\mathrm{CV} / \mathrm{Fe}^{2+}} \\
\left(\mathrm{L} \mathrm{mol}^{-1}\right)\end{array}$ & $\begin{array}{c}\mathrm{K}_{\mathrm{CV} / \mathrm{Ag}}^{+} \\
\left(\mathrm{L} \mathrm{mol}^{-1}\right)\end{array}$ & $\begin{array}{l}\mathrm{K}_{\mathrm{CV} / \mathrm{cd}^{2+}} \\
\left(\mathrm{L} \mathrm{mol}^{-1}\right)\end{array}$ \\
\hline $3 a$ & $8.00 \times 10^{2}$ & - & $3.40 \times 10^{2}$ & - \\
\hline $3 \mathbf{b}$ & $8.13 \times 10^{2}$ & - & - & $2.74 \times 10^{3}$ \\
\hline $3 c$ & $1.38 \times 10^{3}$ & - & - & - \\
\hline 3d & $2.87 \times 10^{2}$ & $3.99 \times 10^{3}$ & - & - \\
\hline
\end{tabular}

\begin{tabular}{|c|c|c|c|c|}
\hline \multicolumn{5}{|c|}{$\begin{array}{r}\text { TABLE-2 } \\
\text { THE BINDING CONSTANTS }\end{array}$} \\
\hline Compound & $\begin{array}{c}\mathrm{K}_{\mathrm{a} / \mathrm{Fe}}^{3+} \\
\left(\mathrm{L} \mathrm{mol}^{-1}\right) \\
\end{array}$ & $\begin{array}{c}\mathrm{K}_{\mathrm{a} / \mathrm{Fe}^{2+}}^{2+} \\
\left(\mathrm{L} \mathrm{mol}{ }^{-1}\right)\end{array}$ & $\begin{array}{c}\mathrm{K}_{\mathrm{a} / \mathrm{Ag}}^{+} \\
\left(\mathrm{L} \mathrm{mol}^{-1}\right) \\
\end{array}$ & $\begin{array}{c}\mathrm{K}_{\mathrm{alcd}}^{2+} \\
\left(\mathrm{L} \mathrm{mol}^{-1}\right) \\
\end{array}$ \\
\hline $3 \mathbf{a}$ & $4.63 \times 10^{2}$ & - & $1.68 \times 10^{3}$ & - \\
\hline $3 b$ & $1.41 \times 10^{3}$ & - & - & $8.48 \times 10^{4}$ \\
\hline $3 c$ & $4.61 \times 10^{3}$ & - & - & - \\
\hline 3d & $3.03 \times 10^{2}$ & $2.04 \times 10^{3}$ & - & - \\
\hline
\end{tabular}

donor group introduced to benzene ring can improve the electron density of coordination site, which was beneficial to the insert of ferric ion. For compound 3a, it showed the best recognition ability to silver ion, with binding constant $K_{a} 1.68$ $\times 10^{3} \mathrm{M}^{-1}$. For componds $\mathbf{3 b}$ and $\mathbf{3 d}$, they displayed the best recognition ability to cadmium ion and ferrous ion, respectively, with binding constant $\mathrm{K}_{\mathrm{a}} 8.48 \times 10^{4}$ and $2.04 \times 10^{3} \mathrm{M}^{-1}$. For compond 3c, it demonstrated selective recognition on ferric ion.

The UV-visible absorption spectra of the compounds 3a-3d with ferric and potass ions system were also selectively measured to further confirmed the metal ions recognition. As shown in Fig. 3(A), it can be seen that the UV-visible absorption spectra 3a-3d decreased as the addition of ferric ion, while that of 3a-3d with potassium ion displayed no change as shown in Fig. 3(B). The phenomenon was consistent with that in fluorescence quenching spectroscopy, confirming the metal ions recognition of compounds $\mathbf{3 a - 3 d}$.
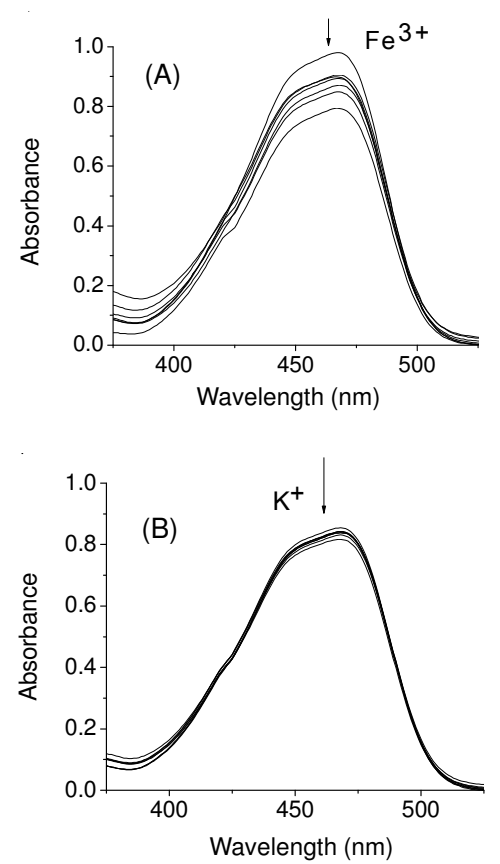

Fig. 3. UV-VIS absorption spectra of the compound $\mathbf{3 a}$ with ferric (A) and potassium (B) ions

\section{Conclusion}

Four naphthalimeds 3a-3d were synthesized and their metal ions recognition was evaluated. The results showed that compounds 3a-3d displayed important metal ions recognition abilities.

\section{ACKNOWLEDGEMENTS}

This study was supported by the Fund of Guangxi Key Laboratory of Functional Phytochemicals Research and Utilization (No. FPRU2011-6) and the Guangxi Department of Education research project (No. 201012MS201).

\section{REFERENCES}

1. A.X. Trautwein, Bioinorganic Chemistry, Wiley-VCH, Weinheim, Germany (1997).

2. B.A. Fowler and P.L. Goering, In ed.: E. Merian, Antimony, Metals and their Compounds in the Environment: Occurrence, Analysis and Biological Relevance, Weinheim, VCH, pp. 743-750 (1991).

3. B. Valeur and I. Leray, Coord. Chem. Rev., 205, 3 (2000).

4. A.P. De Silva, D.B. Fox, T.S. Moody and S.M. Weir, Pure Appl. Chem., 73, 503 (2001).

5. G.W. Gokel, W.M. Leevy and M.E. Weber, Chem. Rev., 104, 2723 (2004).

6. Y.C. Wang, Y. Zhang, X.H. Yi and W. Qin, Asian J. Chem., 24, 323 (2012).

7. K. Haupt and K. Mosbach, Chem. Rev., 100, 2495 (2000).

8. A.P. de Silva, B. McCaughan, B.O.F. McKinney and M. Querol, J. Chem. Soc., Dalton Trans., 1902 (2003).

9. A.P. De Silva, H.Q.N. Gunaratne, T. Gunnlaugsson, A.J.M. Huxley, C.P. McCoy, J.T. Rademacher and T.E. Rice, Chem. Rev., 97, 1515 (1997).

10. B. Ramachandram, G. Saroja, N.B. Sankaran and A. Samanta, Phys. Chem. B, 104, 11824 (2000).

11. H.F. Ji, R. Dabestani and G.M. Brown, J. Am. Chem. Soc., 122, 9306 (2000).

12. M.R. Eftink, In ed.: T.G. Dewey, Fluorescence Quenching Reactions, Biophysical and Biochemical Aspects of Fluorescence Spectroscopy, Plenum Press, New York, pp. 1-44 (1991).

13. J.R. Lakowicz, Principles of Fluorescence Spectroscopy, Plenum Press, New York, p. 698 (1999). 